\title{
Sustainabiliy Analysis of Mariculture Management In Saleh Bay of Sumbawa District
}

\author{
Muhammad Marzuki \\ Aquaculture Study Programme of Mataram University \\ E-mail: marzuki_rina@yahoo.co.id
}

\begin{abstract}
I Wayan Nurjaya
Department of Science and Marine Technology, Bogor Agricultural Institute
\end{abstract}

Ari Purbayanto

Department of Fisheries Resource Utilization, Bogor Agricultural Institute

Sugeng Budiharso

Management Study Programme of Natural Resource and Environment

Bogor Agricultural Institute

Eddi Supriyono

Departement of Aquaculture Bogor Agricultural Institute

Received: August 6, 2014 Accepted: August 19, 2014

doi:10.5296/emsd.v3i2.6427 URL: http://dx.doi.org/10.5296/emsd.v3i2.6427

\begin{abstract}
This study aims to determine the value of the index and the sustainability status of aquaculture management for commodity of long line cultured seaweeds and floating cage cultured humpback grouper existing condition and currently formulating short, medium and long term scenarios for mariculture management in Saleh Bay of Sumbawa District. Sustainability analysis conducted by the method of Rap-Insus-Seaweed (Rapid Appraisal of Sustainability-Index Seaweed) and Rap-Insus-Grouper (Rapid Appraisal of
\end{abstract}


Sustainability-Index Grouper) has been modified from Rapfish program.The results showed that the value of a multidimensional index of sustainability management seaweed culture currently obtained value of 46.82 and the floating cage culture of humpback grouper values obtained 39.47. Multidimensional sustainability index value lies in the range of 25.00 to 49.9, so the status categorized as "Less Sustainable". Sustainability index value of seaweed culture management on short and medium-term scenario increased to 63.45 and the long-term scenario increased to 75.50 , so the status of sustainability in the short and medium-term scenario remains "Fairly Sustainable", while in the long-term scenario status of sustainability increased to "Highly Sustainable". Whilts the value of sustainability index floating cage culture of humpback grouper culture management on short and medium-term scenario increased to 48.10 and the long-term scenario increased to 70.97 , so the status of sustainability in the short and medium-term scenario remains "Less Sustainable", while in the long-term scenario status of sustainability increased to " Highly Sustainable ".

Keywords: Sustainability Analysis, Mariculture, Multi Dimensional Scaling, Saleh Bay

\section{Introduction}

Sumbawa District has the potential mariculture area approximately $69 \%$ of total area for mariculture in West Nusa Tenggara (Zamroni et al, 2007). Saleh Bay is one of Waters being the priority for mariculture development. Mariculture potency of Sumbawa District has been donated more than $70 \%$ of Saleh Bay waters potency. In the last five years, this Saleh Bay waters donated more than $45 \%$ of Sumbawa District mariculture production (Marine and Fisheries Service of West Nusa Tenggara, 2009).

Mariculture is fisheries resource utilization activity being able to give the contribution on area revenue, improvement of public welfare through the provision of new jobs and the country's foreign exchange earnings (Mansyur, 2005). To improve coastal society welfare and contribute fisheries sector on regional economy, the regional government established a priority program namely the increasing of fisheries production in Saleh Bay as center of mariculture production.

Mariculture activity has the dynamics and complex problem related to the activity in the land area. It will give effect on biophysical condition and waters carrying capacity, socio-economic conditions, institutional, and culture technology that are interconnected to form a complex system. The dynamics and complexity of problems faced in the current is a dynamic process realized as a set of event possible wanted in the future depended on the policy being taken at this time.

Therefore, to support the implementation of Government policy to make Saleh Bay as the center of mariculture development production it is required a multidimensional approach.This policy will result in the concept of sustainable development that is able to ensure the ecosystems sustainability by giving the attention on environment capacity limitation. Finally, it will continuously provide economic benefits to the society and regional economy.

Based on the problems above, this study aims to (1) analyze index and sustainability status of mariculture management in Saleh bay of Sumbawa District based on the dimension of ecological, economic, social, technological, and institutional; (2) formulate the scenarios of 


\section{Macrothink \\ Environmental Management and Sustainable Development \\ ISSN 2164-7682 \\ 2014, Vol. 3, No. 2}

short, medium and long-term of the sustainability mariculture management.

\section{Method}

\subsection{Place and Time of Study}

This study was done in Saleh Bay of Sumbawa District. Data was collected from 4 subdistrics namely subdistrict of Moyo Hilir, Lape, Maronge, and Terano. The research was conducted on January to December 2011.

\subsection{Kind and Data Source}

Data required were primary and secondary data related to the attributes of sustainability development dimension namely the dimensions of ecological, economic, social, technological, and infrastructure as well as legal and institutional. Primary data was obtained from direct observation in the field and respondents as well as the selected experts. Meanwhile, secondary data was collected from the library and document of the establishments associated with research.

\subsection{Data Collection Method}

Primary data were obtained through field observation, interview with communities and community leaders, businessmen, and government officials. Detail discussion was conducted with experts including academics, NGOs, government officials, and community leaders. Secondary data were collected from various sources such as District and Dalam Angka Regency, document of Sumbawa District State and saleh Bay State as well as other relevant research results.

\subsection{Data Analysis}

Index Analysis and Mariculture Management Sustainability Status in Saleh Bay of Sumbawa Regency

Analysis of mariculture management sustainability for sea weed and grouper commodities with floating net cage system in Saleh Bay, Sumbawa Regency was done by using Multi Dimensional Scaling (MDS) method with the technique of Rap-Insus Seaweed and Rap-Insus Grouper modified from Rapfish programme (Kavanagh, 2001; Pitcher and Preikshot, 2001; Fauzi and Anna, 2002). MDS method is a statistic technique computer-based using SPSS software. It has been developed from Rapfish G77 Alscal (VBA and Excel) progamme to Simple Rap Insus Mariculture Alglib (.net Windows Aplication) programme being easier in operating and doing transformation on every dimension as well as multidimension of mariculture management sustainability in Saleh Bay. Determination of each attribute in the dimension of the ecological, economic, social-cultural, technological and infrastructure as well as legal and institutional refered to indicator of Rapfish (Kavanagh, 2001; Tesfamichael and Pitcher, 2006; Charles, 2000, and Nikijuluw, 2002) with some modifications.

The attribute of each dimension and the criteria of good or bad followed the concept of Rapfish (Kavanagh, 2001) and judgement knowladge of expert/stakeholder. Every attribute was estimated its score namely; score of 3, 0 and 0-3 for good, bad and between good and bad 
conditions, respectively. Score is the value of modus analyzed to determine dots reflecting the relative sustainability position on the good and bad dot through MDS statistic ordination technique. Estimation score of every dimension was expressed from bad scale (0\%) to good scale $(100 \%)$ and grouped into four categories namely; 0-25.00 \% (bad or unsustainable), $25.01-50.00 \%$ (less sustainable), 50.01-75.00\% (fairly sustainable), and 75.01-100.00\% (higly sustainable)

Ordination technique or distance determination in MDS based on Euclidian Distances in which according to $\mathrm{n}$ dimension it can be written as followed:

$$
d=\sqrt{\left(\left|\mathrm{x}_{1}-\mathrm{x}_{2}\right|^{2}+\left|\mathrm{y}_{1}-\mathrm{y}_{2}\right|^{2}+\left|\mathrm{z}_{1}-\mathrm{z}_{2}\right|^{2}+\ldots \ldots\right)}
$$

Later, configuration or ordination of an object or a point in the MDS was approximated by regressing the distance of Euclidian (dij) from point $i$ to point $j$ with the origin point ( $\sigma \mathrm{ij}$ ) as the following equation:

$$
d_{i j}=\alpha+\beta \delta_{i j}+\varepsilon
$$

Technique used to regress the equation above was Algoritma ALSCAL (Alder et al.,2000 in Fauzi and Anna, 2005). It was a suitable method for Rapfish and had by almost all of statistic software (SPSS and SAS). ALSCAL method optimizes square distance (dijk) on quadrate data or origin point (oijk), in which in three dimensions ( $\mathrm{i}, \mathrm{j}, \mathrm{k}$ ) were well known as S-Stress equation as followed:

$$
s=\sqrt{\frac{1}{m} \sum_{k=1}^{m}\left[\frac{\sum_{i} \sum_{j}\left(d_{i j k}^{2}-o_{i j k}^{2}\right)^{2}}{\sum_{i} \sum_{j} o_{i j k}^{4}}\right]}
$$

Square distance is the distance of Euclidian with the equation as followed:

$$
d^{2}=\sum_{\alpha=i}^{r} w_{k a}\left(x_{i a}-x_{j a}\right)^{2}
$$

Goodness of fit in MDS is reflected of S-Stress value counted based on the value of S and R2. The low stres value shows good fit whilst, the high $S$ value exhibits bad fit. In Rapfish, the good model is shown by the stress value $(S)<0.25$ whilst, the good $R 2$ value is $S$ value approaching 1 (Malhotra, 2006). Evaluation of random error influence (Error) used Monte Carlo analysis to determine: (a) the influence of attribute score making error, (b) variation influence of score giving, (c) stability of repetitive MDS analysis, (d) missing data, and (e) stress value can be accepted if it has S <20\% (Pitcher and Preikshot, 2001).

\subsection{Analysis of Scenario and Strategies for short, intermediate and Long TermScenarios}

Analysis of scenario and strategies for short, intermediate and long term scenarios of sustainability mariculture management was done by quantitative descriptive method. The 
formulation of scenario was based on the attribute having the biggest RMS value and there was done a repair effort to increase the $\mathrm{S}$ score value.

\section{Results and Discussions}

\subsection{Index and Sustainability Status of Ecological Dimension}

Rap Insus Seaweed and Rap Insus Grouper analysis result of mariculture management in Saleh bay, Sumbawa Regency on 10 attributes influenced to ecological dimension with the sustainability index value of ecological dimension for sea weed and grouper namely 52.81 and 54.87 , respectively. This index value was in the range of 50.00-74.9 meaning fairly sustainable. If this condition is left as it is currently it will have an effect on the other dimensions sustainability. As the result, mariculture management in Saleh Bay will more unsustainable.

\subsection{Index and Sustainability Status of Economic Dimension}

Rap Insus Seaweed and Rap Insus Grouper analysis result of mariculture management in Saleh bay, Sumbawa Regency on 10 attributes also influenced to economic dimension with the sustainability index value of ecological dimension for sea weed and grouper namely 51.29 and 44.50 , respectively. Sea weed index value was in the range of 50.00-74.90 indicating fairly sustainability whilst grouper index value was in the range of $25.00-49.90$ expressing less sustainable. If this condition is left as it is currently it will have an effect on the other dimensions sustainability. As the result, mariculture management in Saleh Bay will more unsustainable.

\subsection{Index and Sustainability Status of Social Dimension}

Similar to index and sustainability status of ecological and economic dimension, Rap Insus Seaweed and Rap Insus Grouper analysis result of mariculture management in Saleh bay of Sumbawa Regency on 10 attributes also influenced to social dimension with the sustainability index value of social dimension for sea weed and grouper namely 47.02 and 28.32, respectively. These index values were in the range of 25.00-49.90 meaning less sustainable.

\subsection{Index and Sustainability Status of Institutional Dimension}

Rap Insus Seaweed and Rap Insus Grouper analysis result of mariculture management in Saleh bay of Sumbawa Regency on 10 attributes also influenced to institutional dimension with the sustainability index value of institutional dimension for sea weed and grouper namely 32.38 and 23.41, respectively. These index values were also in the range of 25.00-49.90 meaning less sustainable. If this condition is left as it is currently it will have an effect on the other dimensions sustainability. As the result, mariculture management in Saleh Bay will more unsustainable.

\subsection{Index and Sustainability Status of Technological Dimension}

Rap Insus Seaweed and Rap Insus Grouper analysis result of mariculture management in Saleh bay of Sumbawa Regency on 10 attributes also influenced to technological dimension with the sustainability index value of institutional dimension for sea weed and grouper namely 41.62 and 32.24 , respectively. These index values were also in the range of 
25.00-49.90 meaning less sustainable. If this condition is left as it is currently it will have an effect on the other dimensions sustainability. As the result, mariculture management in Saleh Bay will more unsustainable.

\subsection{Leverage Factor}

Rap Insus Seaweed and Rap Insus Grouper analysis result of mariculture management in Saleh bay, Sumbawa Regency on 49 attributes of the fifth dimensions above was obtained 21 leverage factors for sea weed and 22 leverage factors for floating net cage-culture system. The change of this leverage faktor will be easier to give the effect on index value and sustainability status. In detail, leverage factor of each sustainability dimension of mariculture management in Saleh Bay is presented in Table 1.

Table 1. Key attribute of the fifth dimensions of mariculture management sustainability in Saleh Bay of Sumbawa District

\begin{tabular}{|c|c|c|c|}
\hline Leverage factor of sea weed culture & RMS & Leverage factor of floating net cage culture & RMS \\
\hline \multicolumn{4}{|l|}{ Ecological Dimension } \\
\hline Threats against waters & 0,80 & Threats against waters & 2,70 \\
\hline Threats against waters & 0,73 & Sedimentation level & 1,44 \\
\hline Pest attacks & 0,73 & Status of waters fertility & 1,29 \\
\hline \multicolumn{4}{|l|}{ Economic Dimension } \\
\hline Efficiency of marketing chain & 1,96 & Floating net cage ownership & 7,76 \\
\hline Price fluctuation & 1,85 & Profit transfer & 4,59 \\
\hline Status of business capital & 1,38 & Cultivation labor income & 3,81 \\
\hline Commodity plus value & 1,19 & Subsidy level & 3,12 \\
\hline \multicolumn{4}{|l|}{ Social Dimension } \\
\hline Subsidy level & 3,37 & Human resource availability & 4,36 \\
\hline Education level & 3,08 & Number of cultivation businessman & 3,83 \\
\hline Independence level & 2,37 & Capital social & 3,72 \\
\hline Number of sea weed farmers & & Cultivation labor availability & 4,44 \\
\hline \multicolumn{4}{|l|}{ Institutional Dimension } \\
\hline Institutional of nursery & 3,61 & Regional government support and commitment & 3,35 \\
\hline Institutional of market & 3,05 & Coordination among stakeholders & \\
\hline Institutional of quality quarantee & 2,76 & Institutional of farmers & 3,33 \\
\hline Regional government support and commitment & & Institutional of seeding & 3,10 \\
\hline \multirow[t]{2}{*}{ Institutional of instructor } & 1,82 & Institutional of Instructor & 3,05 \\
\hline & 1,70 & & 2,73 \\
\hline Technological Dimension & & Seed availability & \\
\hline Processing industry & 3,35 & Seeding technology mastery & 4,41 \\
\hline Seed availability & 2,47 & Technology of information and marketing & \\
\hline Means of drying & 1,66 & Cultivation technology mastery & 4,23 \\
\hline Means of warehousing & 1,66 & Infrastructure availability of floating net cage & 4,21 \\
\hline \multirow[t]{2}{*}{ Harvest age exactness } & 1,53 & & 3,27 \\
\hline & & & 1,78 \\
\hline
\end{tabular}




\section{Macrothink}

Source: Analysis result (2012)

Note: Laverage factor $=$ factor root mean square $(\mathrm{RMS})$ value in the meadle until the highest

\subsection{Index and Multidimension Sustainability Status}

Rap Insus Seaweed and Rap Insus Grouper analysis result of mariculture management in Saleh Bay of Sumbawa District for the three dimensions of sea weed culture management showed the sustainability index value in the score range of 25.00-49.90 indicating that it was in category status of less sustainable. The similar category was also exhibited by dimension of ecological, economic and social in management of floating net cage cultivation. Meanwhile, dimension index value of institutional and technological had the sustainability index value more than 24.90 meaning that these two dimensions were in the category of unsustainability. The sustainability index value of the fifth dimensions are visualized in kite diagram presented in Figure 1.

To determine multidimension sustainability status of mariculture management in Saleh Bay of Sumbawa District was obtained by doing pair wise comparison test based on experts opinion in the field of mariculture management to obtain the value of the weighted weight then multiplied by the value of sustainability index value of each dimension (Budiharsono, 2007). Based on the weighting of the fifth of sustainability dimensions there was obtained multidimension sustainability index value of sea weed culture management and that of sea weed culture management with floating net cage system namely; 42.26 and 31.44, respectively. The result analysis of Rap Insus Seaweed dan Rap Insus Grouper for multidimension mariculture management of sea weed culture and floating net cage culture was found the index value of 42.26 and 31.44, respectively. These values were in the range of 25.00-49.90 expressing less sustainability category. Existing condition of sea weed culture management in Saleh Bay have had still less supported the sustainability compared to sea weed culture condition in the other areas. The sustainability of sea weed culture management in the coastal area of Bantaeng Regency was obtained the sustainability index value of $54.11 \%$ meaning that it was in the category of firly sustainability (Yulianti, 2011). In detail, multidimension index value of sea weed culture management in Saleh Bay of Sumbawa District based on the weghting result is presented in Table 2.
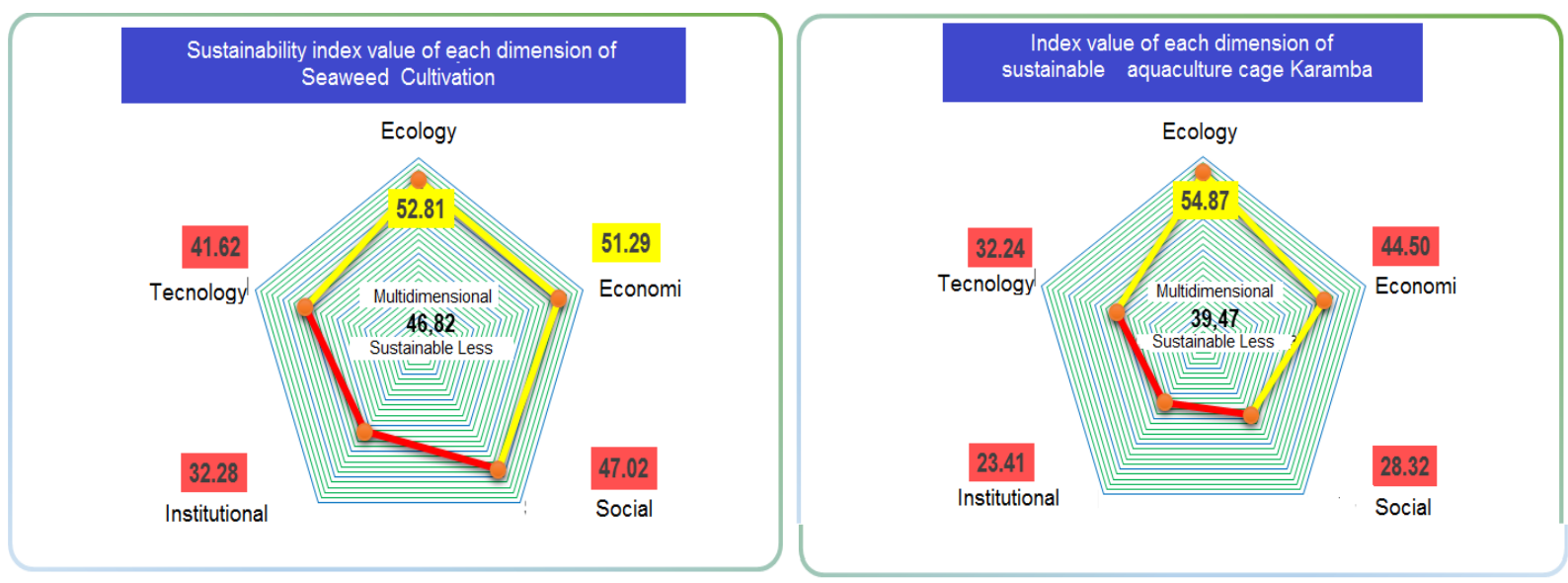
Figure 1. Kite diagram of Existing Condition of Mariculture Management in Saleh Bay of Sumbawa District

Table 2. Multidimension Index Value of Sea weed Culture Management in Saleh Bay of Sumbawa District

\begin{tabular}{|l|c|c|c|c|r|r|}
\hline \multicolumn{1}{|c|}{ Dimension } & \multicolumn{2}{c|}{$\begin{array}{c}\text { The weighted weight } \\
\text { value }(\%)\end{array}$} & \multicolumn{2}{c|}{ Sustainability Index Value } & \multicolumn{2}{c|}{ Weighting Index value } \\
\hline & $\begin{array}{c}\text { Sea } \\
\text { weed }\end{array}$ & $\begin{array}{c}\text { Floating } \\
\text { net cage }\end{array}$ & Sea weed & $\begin{array}{c}\text { Floating net } \\
\text { cage }\end{array}$ & Sea weed & $\begin{array}{c}\text { Floating net } \\
\text { cage }\end{array}$ \\
\hline Ecological & 29.24 & 23.34 & 52.81 & 54.87 & 15.31 & 15.91 \\
\hline Economic & 23.34 & 29.24 & 51.29 & 44.50 & 9.87 & 10.24 \\
\hline Social & 21.46 & 15.14 & 47.02 & 28.32 & 4.84 & 5.95 \\
\hline Institutional & 15.14 & 10.82 & 32.38 & 23.41 & 4.99 & 3.51 \\
\hline Technological & 10.82 & 21.46 & 41.62 & 32.24 & 46.82 & 39.47 \\
\hline & 100 & 100 & & & &
\end{tabular}

Source: Analysis result (2013)

\subsection{Monte Carlo Analysis}

Monte Carlo Analysis showed that the sustainability index value of coral reef ecosystem management on a $95 \%$ confidence level exhibited that the analisis of Rap Insus Seaweed and Rap Insus Grouper between analysis of MDS and Monte Carlo did not show any significant difference (Table 2). The low difference of both analysis showed that; (1) the error in making score in attribute was relatively small, (2) the giving diversity of score due to difference of opinion was relatively small, (3) the analysis process repeatedly done was relatively stable, and (4) the error in data entry and lost data can be avoid.

Table 2. Monte Carlo Analysis for Rap Insus Seaweed and Rap Insus Grouper value on a $95 \%$ confidence level of sea weed culture management in Saleh Bay of Sumbawa District

\begin{tabular}{|l|c|c|c|c|c|c|}
\hline \multicolumn{1}{|c|}{ Dimension } & \multicolumn{2}{|c|}{ MDS Analysis } & \multicolumn{2}{c|}{ Monte Carlo Analysis } & \multicolumn{2}{c|}{ Difference (MDS-MC) } \\
\hline & Sea weed & Floating net cage & Sea weed & Floating net cage & Sea weed & Floating net cage \\
\hline Ecological & 52.81 & 54.87 & 52.55 & 52.55 & 0.26 & 0.67 \\
\hline Economic & 51.29 & 44.50 & 50.93 & 50.93 & 0.36 & 0.01 \\
\hline Social & 47.02 & 28.32 & 46.76 & 46.76 & 0.26 & 1.22 \\
\hline Institutional & 32.38 & 23.41 & 32.93 & 32.93 & 0.55 & 0.81 \\
\hline Technological & 41.62 & 32.24 & 41.72 & 41.72 & 0.10 & 1.09 \\
\hline
\end{tabular}

Source: Analysis result (2013)

The analysis of Rap Insus Seaweed and Rap Insus Grouper showed that all attributes eximined on sustainability status of mariculture management in Saleh Bay of Sumbawa District were quite accurate and accountable. It was indicated by the stress value $<0.25$ and determination coefissien value $\left(\mathrm{R}^{2}\right)$ of 0.94 . As reported by Fauzi and Anna (2005) that the analysis result was sufficient if the stress value was less than $0.25(25 \%)$ and determination coefisient value approaching 1.00. In detail, the stress value and determination coefisient of Rap-Insus Seaweed and Rap-Insus Grouper with Monte Carlo analysis of mariculture sustainability in Saleh Bay of Sumbawa District are presented in Table 3.

Table 3. The stress value and determination coefisient of Rap-Insus Seaweed and Rap-Insus Grouper analysis with Monte Carlo Analysis of mariculture management in Saleh Bay of 
Sumbawa District

\begin{tabular}{|l|c|c|c|c|c|c|c|c|}
\hline \multirow{2}{*}{ Dimension } & \multicolumn{2}{|c|}{$\begin{array}{c}\text { Sustainability } \\
\text { index value }\end{array}$} & \multicolumn{2}{c|}{ Stress } & \multicolumn{2}{c|}{$\mathrm{R}^{2}$} & \multicolumn{2}{c|}{ Iteration } \\
\cline { 2 - 10 } & $\begin{array}{c}\text { Sea } \\
\text { weed }\end{array}$ & $\begin{array}{c}\text { Floating net } \\
\text { cage }\end{array}$ & $\begin{array}{c}\text { Sea } \\
\text { weed }\end{array}$ & $\begin{array}{c}\text { Floating net } \\
\text { cage }\end{array}$ & $\begin{array}{c}\text { Sea } \\
\text { weed }\end{array}$ & $\begin{array}{c}\text { Floating net } \\
\text { cage }\end{array}$ & $\begin{array}{c}\text { Sea } \\
\text { weed }\end{array}$ & $\begin{array}{c}\text { Floating net } \\
\text { cage }\end{array}$ \\
\hline Ecological & 52.81 & 54.87 & 0.13 & 0.13 & 0.94 & 0.94 & 2 & 2 \\
\hline Economic & 51.29 & 44.50 & 0.13 & 0.13 & 0.95 & 0.95 & 2 & 2 \\
\hline Social & 47.02 & 28.32 & 0.13 & 0.13 & 0.95 & 0.94 & 2 & 2 \\
\hline Institutional & 32.38 & 23.41 & 0.14 & 0.13 & 0.95 & 0.95 & 2 & 2 \\
\hline Technological & 41,62 & 32,24 & 0,14 & 0,14 & 0,94 & 0,95 & 2 & 2 \\
\hline
\end{tabular}

Source: Analysis result (2013)

\subsection{Scenario and Strategy of Short, Medium and Long Terms of Sustainability Mariculture} Management in Saleh Bay of Sumbawa District

The analysis of Rap-Insus Seaweed and analisis Rap-Insus Grouper on the key attribute done with the score addition to determine the improvement of index value and sustainability status of mariculture management at the scenarios of short, medium and long terms in this current time. The sustainability index value of sea weed culture management at the scenario of short and medium as well as long terms improved from 46.82-63.45 and 46.82-75.50, respectively. It meaned the sustainability status improved from less sustainable to fairly sustainable and higly sustainable. The sustainability index value of floating net cage culture management at the scenario of short and medium as well as long terms improved from 39.47-48.10 and 39.47-70.97, respectively. It indicated that the sustainability status at the scenarios of short and medium terms was still less sustainability and that at long term scenario improved to be very sustainability. In general, the position of index value of the sustainability of the five dimensions of mariculture management at existing condition, short, medium and long term conditions is shown by Figure 2. Meanwhile, the sustainability index value of the five dimensions of mariculture management at existing condition, short, medium and long term conditions is presented Table 4.

Table 4. The Sustainability Index Value of Mariculture Management in Saleh Bay of Sumbawa District at Existing condition and the scenarios of short, medium and long terms

\begin{tabular}{|c|c|c|c|c|c|c|}
\hline \multirow{3}{*}{ Dimension } & \multicolumn{6}{|c|}{ Value of Sustainability Index } \\
\hline & \multicolumn{2}{|c|}{ Existing } & \multicolumn{2}{|c|}{ Scenario 1} & \multicolumn{2}{|c|}{ Scenario 2} \\
\hline & $\begin{array}{c}\text { Sea } \\
\text { weed }\end{array}$ & $\begin{array}{l}\text { Floating } \\
\text { net cage }\end{array}$ & $\begin{array}{c}\text { Sea } \\
\text { weed }\end{array}$ & $\begin{array}{l}\text { Floating } \\
\text { net cage }\end{array}$ & $\begin{array}{c}\text { Sea } \\
\text { weed }\end{array}$ & $\begin{array}{l}\text { Floating } \\
\text { net cage }\end{array}$ \\
\hline Ecological & 15.31 & 15.91 & 22.15 & 16.36 & 24.38 & 24.97 \\
\hline Economical & 11.80 & 10.24 & 16.07 & 12.61 & 20.03 & 19.84 \\
\hline Social & 9.87 & 5.95 & 11.64 & 7.49 & 12.91 & 8.99 \\
\hline Institutional & 4.84 & 3.51 & 7.06 & 5.74 & 8.71 & 7.69 \\
\hline Technologica; & 4.99 & 3.87 & 6.52 & 5.91 & 9.46 & 9.47 \\
\hline Value of Multidimension Index & 46.82 & 39.47 & 63.45 & 48.10 & 75.50 & 70.97 \\
\hline
\end{tabular}




\section{Macrothink}

Source: (Analysis result, 2013)
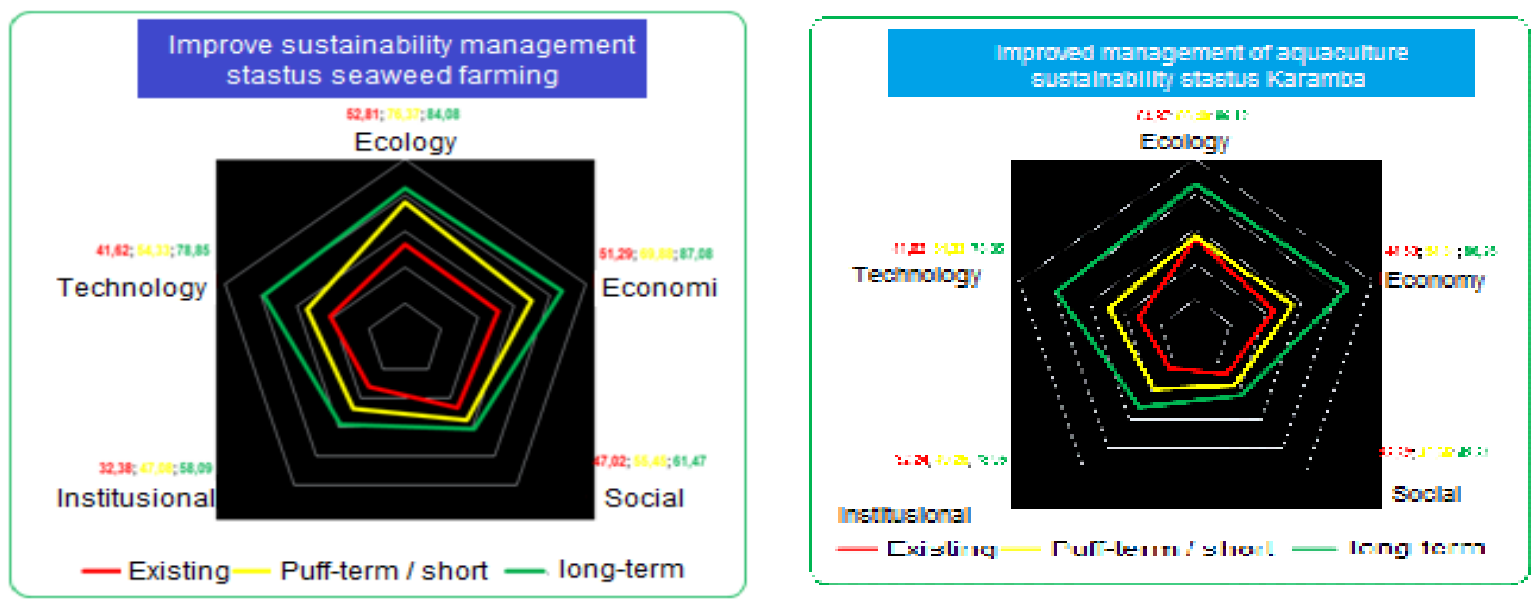

Figure 2. Kite diagram of the sustainability

index value at the existing condition, the scenarios of short, medium and long terms of mariculture management in saleh bay of Sumbawa District

The sustinability status improvement of floating net cage culture management, ecological, technological, economic, institutional, social, existing, short and moderate terms, long term.

\section{Conclussions and Suggestions}

\subsection{Conclussions}

The sustainability status of mariculture management in the current time in Saleh Bay of Sumbawa District for sea weed and floating net cage culture was less sustainable.

The sustainability status of sea weed culture management based on the scenarios of short and medium term was fairly sustainable whilst, long term scenario was higly sustainable.

The sustainable status of floating net cage culture based on the scenarios of short and medium terms was less sustainable whilst, that based on long term was higly sustainable.

\subsection{Suggestions}

It is need to be prioritized the improvement of sustainability dimension having the sustainability index of less sustainability category. maintain and improve the sustainability index of multidimension due to its easiest sustainability level to change to the way of fairly sustainable.

It is need the policy and commitment of local goverment in doing the improvement on the key attribute to be able to increase the index value and the sustainability status of mariculture management.

\section{References}

Alder J, Pritcher T. J., Preikshot D, Kaschner K, \& Ferriss B. (2001). How Good is Good?: A Rapid Appraisal Technique for Evaluation of the Sustainability Status of Fisheries of the North Atlantic. Fisheries Centre. University of British Columbia. Vancouver, Canada. 


\section{Macrothink}

Environmental Management and Sustainable Development

ISSN 2164-7682

2014, Vol. 3, No. 2

Budiharsono, S. (2006). Planning Concept of Sustainability Marine and Fisheries Development In: Plenning System of Marine and Fisheries Development. Planning Agency and Foreign Cooperation, Secretary General of Marine and Fisheries Agency. Jakarta.

Charles A. T. (2000). Sustainability Fishery Systems. Sain Mary's University Halifax, Nova Scotia, Canada. 370 p. Jakarta. http://dx.doi.org/10.1002/9780470698785

Marine and Fisheries Service of West Nusa Tenggara Barat Province. (2009). Detai Plan of Layout of Saleh Bay. Marine and Fisheries Srvice of West Nusa Tenggara. Mataram

Fauzi, A., \& Anna Z. (2005). Modelling of Marine and Fisheries Resource for Policy Analysis. Jakarta, Gramedia.

Fauzi. A, \& Anna, S. (2002). Status Evaluation of Fisheries Development Sustainability, RAPFISH Application, Case Study of DKI Jakarta Coastal Waters. Journal of Coastal and Marine. 4(3).

Pitcher, T. J., \& Preikshot, D. B. (2001). Rapfish: A Rapid Appraisal Technique to Evaluate the Sustainability Status of Fisheries. Fisheries Research 49(3), 255-270. http://dx.doi.org/10.1016/S0165-7836(00)00205-8

Mansyur A. U., Tarunamulis, Pantjara B, \& Hasnawi. (2005). Identification of Mariculture Area Location in Kupang Bay, East Nusa Tenggara. Journal of Indonesian Fisheries Research 11(5), 9-29.

Nikijuluw, V. P. H. (2002). Management Regime of Fisheries Resource. Pustaka Cidesindo Publisher.

Tesfamichael D \& T J Pitcher. (2006). Multidisciplinary Evaluation of the Sustainability of Red Sea Fisheries Using Rapfish. Fisheries Reasearch, 78, 277-235. http://dx.doi.org/10.1016/j.fishres.2006.01.005

Kavanagh P. (2001). Rapid Appraisal of Fisheries (RAPFISH) Project. University of British Columbia, Fisheries Centre.

Yulianti. (2011). Management Optimatization of Sea weed Resource in Coastal Area of Bantaeng Regency, South Sulawesi Province. Ph.D Thesis. Bogor Agricultural Institute. Bogor.

Zamroni A, Apriliani T, \& Hikmayani Y. (2007). Marketing Analysis of Sea Weed in the Potential Area in Indonesia. Journal of Wise da Reastech. MF 2(2), 159-175.

\section{Copyright Disclaimer}

Copyright for this article is retained by the author(s), with first publication rights granted to the journal.

This is an open-access article distributed under the terms and conditions of the Creative Commons Attribution license (http://creativecommons.org/licenses/by/3.0/). 